\title{
Wartościowanie i ironia w tekście w świetle teorii aktów mowy
}

\author{
Valuation and irony in text in the light of speech act theory
}

Katarzyna KUKOWICZ-ŻARSKA ${ }^{1}$

Ateneum-Szkoła Wyższa w Gdańsku

\begin{abstract} and cultural norms. theory

\section{Streszczenie}

1 https://orcid.org/0000-0002-6652-9068

Ateneum-Szkoła Wyższa w Gdańsku, Wydział Neofilologiczny

k.kukowcz@ateneum.edu.pl
\end{abstract}

This article focuses on the issue of valuation and the presence and role of irony in text in the light of speech act theory. The research material used for the analysis comes from the novel by Philip Kerr "March Violets", which is a representative of the historical detective novel genre. The article does not aim to criticize the book's translations, but focuses its attention on the message itself, which, through them, reaches the recipient and makes a specific impression on him/her. This specific impression, evoked by said speech acts and thoughtfully encoded in the text, is subject to the analysis here. Sociolinguistic assumptions have been adopted as the basis for these considerations, which seems to be justified in so far as language within such analytical framework can be treated as a binder among social groups, nations, communities and may play a significant role both in shaping them, shaping their collective beliefs, ideas,

Keywords: evaluation, valuation, irony, axiology, sociolinguistics, text, speech act, speech act

Niniejszy artykuł koncentruje się na zagadnieniu wartościowania, a także obecności i roli ironii w tekście i omawia je w świetle teorii aktów mowy. Materiał badawczy, służący do przeprowadzenia analiz na potrzeby artykułu, pozyskany został z powieści autorstwa Philipa Kerra „March Violets”, reprezentującej gatunek historical detective novel. Artykuł nie obiera 
sobie za cel krytyki dokonanych tłumaczeń, lecz skupia swoją uwagę na samym przekazie, który za ich pośrednictwem dociera do odbiorcy i wywiera na nim określone wrażenie. Owemu wrażeniu właśnie, wywołanemu poprzez przytoczone akty mowy i w sposób przemyślany zakodowanemu w tekście poświęcono część rozważań. Za podstawę owych rozważań przyjęto założenia socjolingwistyki, co wydaje się o tyle zasadne, iż język w ramach tak nakierowanych analiz traktowany być może jako spoiwo grup, narodów, społeczności i pełnić niebagatelną rolę zarówno w kształtowaniu ich samych, jak i kształtowaniu ich zbiorowych przekonań, wyobrażeń i norm kulturowych.

Słowa kluczowe: wartościowanie, ironia, aksjologia, socjolingwistyka, tekst, akt mowy, teoria aktów mowy

\section{Wprowadzenie do rozważań}

Niniejszy artykuł koncentruje się na zagadnieniu wartościowania, a także obecności i roli ironii w tekście i omawia je w świetle teorii aktów mowy. Za podstawę moich rozważań przyjmuję założenia socjolingwistyki, co wydaje się o tyle zasadne, iż język w ramach tak nakierowanych rozważań traktowany być może jako spoiwo grup, narodów, społeczności i pełnić niebagatelną rolę zarówno w kształtowaniu ich samych, jak i kształtowaniu ich zbiorowych przekonań, wyobrażeń i norm kulturowych. Dodatkowo jak stwierdza Grabias (2019, s. 91) „socjolingwistyka, opisując reguły zachowań językowych, winna dążyć do odkrycia systemu społecznych aktów komunikacji”. Za jednostkę opisu przyjmuję zatem akt mowy w rozumieniu Austinowskim² (definiując go w kategoriach działania przez język), stanowiący w szerszym wymiarze element składowy teksu i uwzględniam w tym kontekście „społeczny charakter języka", uznając, iż język jako twór społeczny, jest jednocześnie bytem tworzącym jak i warunkującym istnienie grup społecznych (por. Grabias 2019, s. 17). Dalsze rozważania determinuje zatem stwierdzenie:

W rozważaniach o „społecznym charakterze języka” trzeba mieć na uwadze konsekwencje wynikające $\mathrm{z}$ takiego właśnie, dychotomicznego, ujęcia problemu: język, będąc wytworem społeczeństwa, sam konstruuje życie społeczne. (ibid.)

\footnotetext{
${ }^{2}$ Akty mowy traktuję jako fenomen językoznawczy dobrze znany w literaturze przedmiotu, w związku z tym nie przedstawiam całości rozważań teoretycznych na ten temat. Za podstawę moich rozważań przyjmuję koncepcję Austinowską oraz jej kontynuatorów (Saerle), modyfikując ją jednak w zależności od potrzeb wynikających z analizy. Więcej na temat aktów mowy w tym ujęciu patrz rozdział Jak działać słowami (Austin, 1993, 640-655) oraz Saerle (1980), Lipczuk (2000), Zdunkiewicz (1993). Ciekawie tę tematykę traktuje także Tryńska (2015).
} 
Myśl ta ponownie pojawi się w dalszej części rozważań, gdzie za ową grupę społeczną, której język „będąc wytworem społeczeństwa, sam konstruuje życie społeczne" (ibid.) przyjmiemy społeczeństwo epoki narodowego socjalizmu w Niemczech, a zatem naród jako twór społeczny, jako ogół społeczeństwa, „identyfikowany nie tyle ze wspólnotą ideową, co ze swoistym braterstwem krwi (wspólnotą biologiczną), konceptualizowanym społecznie poprzez kulturową metaforę wielkiej „rodziny” wszystkich Niemców.” (Drozdowicz, 2010, s. 49) ${ }^{3}$.

Odnosząc się do zagadnień samego wartościowania jak również jego korelacji $\mathrm{z}$ teorią aktów mowy $\mathrm{w}$ świetle języka narodowego socjalizmu ${ }^{4}$ powtórzę myśl, którą zawarłam w jednej z wcześniejszych publikacji:

Jako że wybranym elementom rzeczywistości kreowanej przy pomocy języka zwyczajowo przypisujemy oceny, które nie tylko mają odzwierciedlić nasz stosunek do nich, lecz także nierzadko w sposób implicytny mają zmusić odbiorcę komunikatu językowego do określonej i pożądanej przez emitenta reakcji mentalnej lub fizycznej, nie powinien dziwić fakt, iż język narodowego socjalizmu badany jest tu w perspektywie językoznawczej i socjokulturowej. (Kukowicz-Żarska, 2018, s. 61)

Materiał badawczy, służący do przeprowadzenia analiz na potrzeby niniejszego artykułu, pozyskany został z powieści autorstwa Philipa Kerra „March Violets”, reprezentującej gatunek historical detective novel ${ }^{5}$, czy jak w swej recenzji na łamach tygodnika „Polityka” napisał o nim Andrzej Garlicki: „modnym ostatnio połączeniem klasycznej powieści kryminalnej z historycznym reportażem" (Garlicki, 2009). Oryginał powieści powstał w języku angielskim, a jego pierwsze wydanie miało miejsce w roku 1989 nakładem wydawnictwa Viking w Londynie. Tłumaczenia powieści na język niemiecki podjął się Hans J. Schütz (1995) ${ }^{6}$, natomiast przekładu z języka angielskiego na język polski dokonała Ewa Fiszer (2009)7.

\footnotetext{
3 Więcej na temat niemieckiej koncepcji narodu i wspólnoty (w kontekście nazistowskiego okultyzmu) patrz: Drozdowski (2010), a w kontekście wartościowania w języku w myśl idei narodowych: Kukowicz-Żarska (2018).

${ }^{4} \mathrm{Na}$ temat debaty naukowej dotyczącej istnienia zjawiska ,języka narodowego socjalizmu” czytaj Kukowicz-Żarska (2018, s. 65-66).

5 Określanym również mianem historical mystery lub historical whodunit i stanowiącym subgatunek, będący kompilacją dwóch gatunków literackich takich jak: historical fiction oraz mystery fiction.

${ }^{6}$ Pierwsze niemieckojęzyczne wydanie „March Violets” Phillipa Kerra w thumaczeniu Hansa J. Schütza ukazało się w roku 1995, nakładem wydawnictwa Rowohlt w Reinbek. Analizując tekst „Marcowych fiołków” opieram się na niemieckojęzycznym wydaniu specjalnym powieści
} 
Niniejszy artykuł nie obiera sobie za cel jakiejkolwiek krytyki dokonanych tłumaczeń, lecz skupia swoją uwagę na samym przekazie, który za ich pośrednictwem dociera do odbiorcy i wywiera na nim określone wrażenie. Owemu wrażeniu właśnie, wywołanemu poprzez przytoczone akty mowy i w sposób przemyślany zakodowanemu $\mathrm{w}$ tekście $\mathrm{z}$ założenia nadaję znamiona celowości. Mimo, iż wybory, jakich dokonuje tłumacz podczas pracy nad tekstem są fascynujące i z pewnością zasługują na poświęcenie im większej uwagi, artykuł ten stara się koncentrować nie na samym procesie twórczym, prowadzącym do osiągnięcia pożądanego efektu finalnego w postaci danego tłumaczenia, a skupia się on właśnie na owym namacalnym efekcie finalnym i jego sile oddziaływania. To właśnie owe przemyślane, dobrane $\mathrm{z}$ wielką pieczołowitością frazy mają nie tylko w zamierzeniu odzwierciedlić zamysł autora pierwowzoru, lecz także, a może przede wszystkim, przełożone na dany język obcy dotrzeć z określonym przekazem do rodzimego odbiorcy i wywołać u niego pewną reakcję mentalną -wpłynąć bezpośrednio bądź pośrednio na odbiór danych treści, sposób ich postrzegania, a być może nawet zmienić podejście do nich.

\section{Akty mowy w świetle języka narodowego socjalizmu i badań socjolingwistycznych}

Koncepcję aktu mowy $\mathrm{w}$ świetle badań socjolingwistycznych prezentuje Grabias (2019, s. 35-36), a czyni to za Lubasiem, który na bazie zmodyfikowanego przez siebie strukturalistycznego przeciwstawienia langue i parole definiuje akty mowy jako „ukonkretnione realizacje językowe, w których jednostka zużywa częściowo swoje kompetencje jako członek danego społeczeństwa, jako członek danej grupy i częściowo swoje

(Sonderausgabe) z roku 2007, które ukazało się jako wydanie zbiorcze pod tytułem „Die BerlinTrilogie”, nakładem wydawnictwa Rowohlt, Reinbek w roku 2007 i zawierało 3 pierwsze tomy z cyklu Sprawa dla Bernharda Gunthera (Ein Fall für Bernhard Gunther): „March Violet”(Feuer in Berlin), "The pale criminal” (Im Sog der dunklen Mächte) oraz „A German Requiem” (Alte Freunde, neue Feinde).

7 Pierwsze polskojęzyczne wydanie powieści tłumaczone przez Ewę Fiszer ukazało się dopiero w roku 2009, nakładem wydawnictwa Red Horse w Lublinie. Analizując w niniejszym artykule tekst „Marcowych fiołków” opieram się na wydaniu 2. poprawionym z roku 2014 Wydawnictwa W.A.B. w Warszawie, także w tłumaczeniu Ewy Fiszer. 
kompetencje indywidualne jako jeden z przedstawicieli gatunku ludzkiego"8. Grabias (ibid.) następnie konstatuje:

Zatem w aktach mowy człowiek podlega regułom zachowań językowych właściwych grupie społecznej, do której należy, i sam zachowania te kształtuje w sposób odpowiadający jego indywidualnym właściwościom psychicznym.

Grabias stawia przy tym fundamentalne w kontekście teorii komunikacji językowej pytanie: „Na ile jednostka podlega społecznym regułom budowy tekstów, a na ile teksty te kreuje?" Pytanie to wiąże się w sposób bezpośredni z założeniem, poczynionym na początku tego artykułu.

Ponieważ każdy akt mowy z założenia zmienia rzeczywistość $\mathrm{w}$ jakiś sposób, modyfikuje jakiś jej fragment (por. Lipczuk 2000, s. 173), to właściwie każda podlegająca analizie fraza dokonuje określonej ingerencji w umyśle odbiorcy, czyli w kontekście perlokucyjnych skutków wypowiedzi, jak pisze Austin, dokonuje określonych zmian „w sferze uczuć, myśli lub działań słuchaczy" (Austin, 1993, s. 646). Oczywiście rozpoznanie intencji nadawcy warunkuje wpływ danego aktu mowy i jego siłę oddziaływania, jak również stanowi kluczowy element przy interpretacji wypowiedzi, gdyż akty mowy podlegają pewnej konwencji, czyli „muszą zostać spełnione warunki podstawowe, aby dana wypowiedź była skuteczna" (Trysińska, 2015, s. 64). Obok zindywidualizowanego sposobu odbioru treści należy także docenić aspekt kulturowy, który przy odbiorze i interpretacji tekstów, w szczególności takich jak tekst, do którego odnosi się niniejszy artykuł, gra nietuzinkową rolę:

Każdy akt mowy jest bowiem „strukturą usytuowaną", to znaczy powiązaną z kulturowymi i osobistymi zdarzeniami mówiących. Ostatecznie więc nie tylko gramatyka, lecz także społeczne i osobiste zdarzenia uczestników komunikacji decydują o znaczeniu i wewnętrznej budowie wypowiedzi. (Grabias, 2019, s. 39)

W odniesieniu do tytułowego zagadnienia wartościowania przytoczyć można słowa Grunbergera (1989), którymi w sposób niezwykle obrazowy i finezyjny wyraził stosunek opisywanej $\mathrm{w}$ powieści epoki narodowego socjalizmu do języka:

Naziści splądrowali i zanieczyścili język niemiecki z tą samą bezlitosną sumiennością, z jaką traktowali inne zasoby ludzkie i materialne; pozbawili go wszelkiego wdzięku, subtelności, różnorodności. Używali słów nie jako pomostów do umysłu rozmówcy, ale jako harpunów wbijanych w delikatną

${ }^{8}$ Grabias cytuje koncepcje Lubasia na tematy socjolingwistyczne przedstawione w jego publikacji książkowej pt. Społeczne uwarunkowania współczesnej polszczyzny (1979) jak również w licznych artykułach publikowanych w czasopiśmie „Socjolingwistyka”. 
materię jego podświadomości. Rozmaite użycia mowy - jako komunikacji, argumentacji, obrony idei, monologu, modlitwy czy zaklęcia - zredukowali do jednej jedynej funkcji: magicznej. (Grunberger, 1987, s. 387)

Philip Kerr, czyli autor powieści „Marcowe fiołki”, pomimo całego ciężaru gatunkowego, jaki niesie ze sobą okres narodowego socjalizmu w Niemczech, stara się jednak używać słów jako pomostów do umysłu odbiorcy, aby dotrzeć do tej delikatnej materii jego podświadomości i skonfrontować się z nią $\mathrm{w}$ pewien wysublimowany choć zamierzony sposób. W tym właśnie celu wykorzystuje ironię jako element stylizacji wypowiedzi oraz swoisty gwarant adekwatności przekazu, a także ukazuje wartościowanie, które determinuje jego wiarę w skuteczność takiego a nie innego sposobu narracji.

\section{Marcowe fiołki jako podmiot i przedmiot wartościowania}

Szczególnie ciekawym w kontekście niniejszych rozważań wydaje mi się zestawienie poszczególnych aktów mowy w języku niemieckim - jako języku rzeczywistości opisywanej $\mathrm{w}$ powieści oraz ich odpowiedników $\mathrm{w}$ języku polskim, jako tym, dla rodzimych użytkowników którego dyskurs ten jest szczególnie istotny i nadal żywy, a także relacja intencjonalności tekstu do jego akceptowalności. Jeśli intencjonalność jako jedno z kryteriów teksu odnosi się do jego nadawcy (tu: zarówno autora tekstu oryginalnego, jak również pośrednio autora tekstu tłumaczonego), to akceptowalność owego tekstu i jego przekazu wynika z postawy recypienta - czyli odbioru danych aktów mowy w kręgu odbiorców zakładanej grupy docelowej. W odniesieniu do przeprowadzonych analiz jako ową grupę docelową traktuję każdego odbiorcę tekstu władającego danym językiem - w szczególności jednak rodzimego, ze względu na obecność w omawianych aktach mowy dodatkowych elementów socjokulturowych i ich wpływ na odbiór danego działania językowego. Co ciekawe - tłumaczenie poszczególnych fraz na język niemiecki okazało się w większości bardzo wierne i zbliżone w swej strukturze i wydźwięku do języka oryginału, co oznaczać może, iż Philip Kerr jako autor pierwowzoru wykazał się w oczach tłumacza niemieckojęzycznego znaczną biegłością w sferze opisywanej rzeczywistości językowej, a także uchwycił konwencję charakterystyczną dla ówczesnego użycia języka niemieckiego. O ile ze względu na stopień pokrewieństwa obu języków nie dziwią specjalnie zachodzące podobieństwa formalne, ciekawym jednak wydaje się zachowanie wspólnej konwencji dla obu języków w zakresie przekazywania treści 
ironicznych czy wartościujących, np. w opisach sytuacji i miejsc, czy też w języku samego głównego bohatera.

„Marcowe fiołki”, jak informuje wydawca w opisie towarzyszącym pierwszemu polskiemu wydaniu książki (2009), „to powieść otwierająca serię czarnych kryminałów o Bernim Guntherze, ukazujących czytelnikowi niezwykły obraz III Rzeszy u narodzin jej potęgi i po jej upadku”. Akcja powieści rozgrywa się w Berlinie w 1936 roku, w roku letnich igrzysk olimpijskich, odbywających się w stolicy nazistowskich Niemiec. Ten właśnie obraz igrzysk - zarówno przygotowań do nich, jak i poszczególnych momentów z ich przebiegu, a także zapowiedzi sytuacji po ich zakończeniu odgrywa znaczącą rolę $\mathrm{W}$ powieści i motywuje szereg wypowiedzi o charakterze ironicznym, uwzględniających także użycie różnego rodzaju językowych środków wartościowania (m.in. porównania, eufemizmy czy metafory). Jak zaznaczałam w swym wcześniejszym artykule dotyczącym wartościowania oraz „siły słowa i mocy wyrazu” (Kukowicz-Żarska, 2019) językowe środki wartościowania stanowią niezwykły oręż w nacechowanym emocjonalnie języku narodowego socjalizmu.

Poruszając zagadnienia wartościowania i ironii w omawianym tekście warto $\mathrm{w}$ pierwszym rzędzie skupić się na wymiarze samego tytułu powieści. Tytuł w języku polskim "Marcowe fiołki" odpowiada w pełni tytułowi $\mathrm{w}$ języku oryginału, to znaczy w języku angielskim 'March Violets', natomiast $\mathrm{w}$ tłumaczeniu powieści na język niemiecki został on całkowicie zmieniony i zastąpiony tytułem „Feuer in Berlin”. Można pokusić się o próbę skomentowania tak istotnej ingerencji $\mathrm{w}$ ten jakże reprezentatywny element tekstu, patrząc na niego jako na charakterystyczny w swej funkcji akt mowy. Ponieważ powieść w języku niemieckim zdaje się być przetłumaczona wiernie $\mathrm{w}$ kontekście oryginału, dziwi aż tak duża ingerencja w tytuł całej powieści, który przecież stanowi nie tylko zapowiedź, intrygujący wstęp do prezentowanych treści, ale również kierunkowskaz wskazujący czytelnikowi drogę, którą będzie podążać w miarę zagłębiania się w lekturę. Cała powieść opierała się na zakładanej grze słów dotyczącej tzw. marcowych fiołków, sugerowała charakterystyczną grupę społeczną, której w swej treści miałaby dotyczyć, a czego obraz został stworzony w oryginale i zachowany w polskim tłumaczeniu. Brak tej informacji w tytule niemieckojęzycznym nie ukazuje zatem odniesienia bezpośrednio do bohaterów nazywanych marcowymi fiołkami, a zdaje się wprowadzić czytelnika w treść poprzez odwołanie się do 
wydarzenia, jakim było w roku 1933 podpalenie budynku Reichstagu9 Możemy przyjąć, że zarówno w kulturze niemieckiej jak i języku (jednostka Reichstagsbrand, konotująca negatywnie) wydarzenie to pozostawiło wyraźne ślady i posiada tak znaczną moc wartościującą, że w tłumaczeniu przyjęto, iż właśnie ono powinno być forpocztą opisywanych zdarzeń. Sam tytuł możemy w tym kontekście przyjąć za akt mowy o mocy performatywnej - nie ma on funkcji czysto informującej i nie podlega ocenie prawdziwości $\mathrm{w}$ sensie logicznym. Główną rolę gra tu zapowiadany kontekst, a sama moc tytułowej frazy różni się $\mathrm{w}$ zależności od języka. Określenie marcowe fiołki posiada wprawdzie swoją reprezentację w języku niemieckim: Märzveilchen, jednak zdecydowanie częściej pojawia się w tym znaczeniu termin Märzgefallene (Kerr 2007, s. 16, 62, 85, 131, 145). Märzgefallene jest ironicznym, prześmiewczym terminem o silnej podbudowie emocjonalnej, wartościującym jednoznacznie negatywnie, zarówno ówcześnie jak i w dzisiejszych czasach i stanowi pejoratywne określenie oportunistów, którzy wstąpili do NSDAP po wyborach do Reichstagu 5 marca 1933 (por. Schmitz-Berning, 2000, s. 399). Mianem tym określano zatem „nowych członków partii”, którzy zgłosili swój akces do NSDAP dopiero po wygranych przez partię narodowosocjalistyczną wyborach do Reichstagu i którzy zostali oskarżeni przez tak zwanych "starych bojowników" o oportunizm, byli wyszydzani, traktowani $\mathrm{z}$ dystansem i nieufnością. Ponieważ chęć wstąpienia do partii stała się zjawiskiem tak nagminnym, powątpiewano w czystość intencji owych kandydatów. Ten „owczy pęd” wiązał się z jednej strony z pojawieniem się takiej możliwości na szerszą skalę dla tych, którym wcześniej zakazano wstępu do partii, z drugiej zaś strony pojawiło się wielu karierowiczów, chcących osiągnąć wyższy status społeczny jak i zwykłych asekurantów, objawiających się, iż ich sytuacja zawodowa pogorszy się, w przypadku, gdyby nie zostali oni członkami NSDAP. Wytłumaczenie tego zjawiska socjokulturowego pojawiło się $\mathrm{w}$ postaci przypisu $\mathrm{W}$ polskim tłumaczeniu powieści ${ }^{10}$, jednak $\mathrm{W}$ tłumaczeniu niemieckojęzycznym brak jakiejkolwiek wzmianki na ten temat. Co ciekawe

\footnotetext{
9 Pożar gmachu parlamentu Rzeszy w Berlinie (niem. Reichstagsgebäude) miał miejsce w nocy z 27 na 28 lutego 1933 roku i stanowił dla Hitlera pretekst do rozprawienia się z niewygodną opozycją, wprowadzenia na terenie całego kraju stanu wyjątkowego i stał się symbolem wielokrotnie nadużywanym w walce politycznej.

${ }^{10}$ Dopisek w polskiej wersji powieści, pochodzący prawdopodobnie od wydawnictwa, gdyż brak jakiejkolwiek informacji o jego autorstwie tłumaczki Ewy Fiszer, brzmi: „Tytułowymi 'marcowymi fiołkami' nazywano kpiąco karierowiczów masowo wstępujących do partii hitlerowskiej od marca 1933, kiedy to NSDAP zdobyłą przeszło 44\% głosów w wyborach parlamentarnych i dzięki czemu Hitler przejął pełnię władzy w Niemczech" (Kerr, 2007, s. 7).
} 
mianem Märzgefallene nazywano początkowo ofiary Rewolucji Marcowej 1848 roku, które poległy w Berlinie w walkach ulicznych z wojskami pruskimi (por. Schmitz-Berning, 2000, s. 399).

Frapującym pod względem analizy jest także dowcip w formie krótkiego dialogu - wymiana zdań między dwoma anonimowymi mężczyznami. Dowcip pochodzi z pisma „Das Schwarze Korps”, datowany jest na listopad 193511 $\mathrm{i}$ odnosi się $\mathrm{w}$ sposób bezpośredni do tytułu powieści czy też do postaci i postawy samych marcowych fiołków.

Mężczyzna pierwszy: My, weterani, jesteśmy kompletnie lekceważeni. Popatrz na te „marcowe fiołki”, wszystko jest dla nich.

Mężczyzna drugi: Święta racja! Gdyby Führer później wstąpił do partii, zaszedłby dużo dalej. (Kerr, 2014, s. 7)

W wersji polskojęzycznej wypowiedź pierwszego mężczyzny koncentruje się na skardze w akcie pierwszym i wyrażeniem złości i zawiści w drugim akcie mowy. Pojawia się tu zaimek osobowy „my”, który staje się oczywistym podmiotem zdania i tym samym ukazuje grupę osób „uskarżających się”. Dzięki niemu zaznaczono jakże charakterystyczną dla języka doby narodowego socjalizmu (i nie tylko jego) dychotomię my $\neq$ oni. $M y$ (ci dobrzy, wartościowi) $\mathrm{w}$ połączeniu z jednostką leksykalną wartościującą pozytywnie weterani budują zarys konkretnej grupy społecznej, tworząc zbiorowość - wspólnotę społecznonarodową i implikując przy tym należące się jej uznanie, przynależny splendor. Grupa ta jednak owych oznak uznania nie doświadcza, pomimo, iż w dobie narodowego socjalizmu leksem weteran był bardzo istotnym elementem budowania etosu narodowego. Wypowiedź zatem nabiera charakteru aktu ekspresywnego: Weterani czują się kompletnie lekceważeni - właściwie to pojawia się kategoryczne stwierdzenie, że są kompletnie lekceważeni a przyczynę tego stanu rzeczy upatrują właśnie w marcowych fiołkach (tych innych, złych, mało wartościowych). Fakt, że takiemu stanowi rzeczy winna jest ta a nie inna grupa, stanowi jeszcze większą ujmę, gdyż to właśnie marcowe fiołki, oportuniści, osoby niegodne, wręcz kuriozalne, czerpią wszelkie zyski co potęguje zestawienie obu aktów. Oba akty posiadają silny wymiar emocjonalny, obnażają uczucia i na zasadzie analogii i kontrastu wywołują u odbiorcy wrażenie niestabilności ówczesnych relacji społecznych. Tryb rozkazujący nadaje drugiemu aktowi mowy charakteru dyrektywnego, mocy

11 „Das Schwarze Korps” - to tytuł oficjalnej gazety nazistowskiej, będącej organem propagandowym organizacji Schutzstaffel (SS), która wydawana była w latach 1935-1945 i dystrybuowana za darmo, osiągając wysokie nakłady. 
perlokucyjnej - odbiorca współczesny również powinien odnieść wrażenie, że marcowe fiołki to grupa niegodna i jednocześnie niesprawiedliwie nagradzana i jako taką odbierać ją negatywnie. W odpowiedzi interlokutor wyraża swoją aprobatę dla wcześniejszych stwierdzeń - jednoznacznie, wyraźnie, używając wykrzyknienie jako środka wyrazu. Następnie w sposób implicytny komentuje społeczne nastawienie do marcowych fiołków, stwierdzając, że „Gdyby Führer później wstąpił do partii, zaszedłby dużo dalej”, co ukazuje cały emocjonalny ogląd sytuacji - gdyby został on zatem marcowym fiołkiem, kariera sama by do niego przyszła i do tego w znacznie większym wymiarze. Ten akt mowy zdaje się zatem dodatkowo na bazie humoru implikować, iż Hitler w rzeczy samej mógłby dojść znacznie dalej i osiągnąć znacznie więcej, niż to uczynił $\mathrm{w}$ ówczesnej rzeczywistości. Co ciekawe akty mowy w przytoczonym fragmencie zdają się mieć moc podwójną: z jednej strony odnoszą się do relacji nadawca - odbiorca w ramach dialogu, który tworzą, a z drugiej strony do relacji nadawca - odbiorca w kontekście autor - tekst - czytelnik. W tym miejscu warto przytoczyć relacje, jakie na tej bazie tworzą się przy uwzględnieniu występującego $\mathrm{w}$ ich trakcie wartościowania: najpierw zatem pojawia się emocja jako impuls dla produkcji tekstu, następnie wartościowanie jako środek oddziaływania, potem sam tekst jako środek wyrazu, by dotrzeć do recepcji tekstu, jako wyniku procesu produkcyjnego i wreszcie działanie, jako rezultat sprowokowanej przez emocję recepcji tekstu. Ironia zawarta w przytaczanym akcie mowy ma zatem za zadanie wyrazić emocje, które $\mathrm{z}$ jednej strony przyczyniają się do samego powstania tekstu, $\mathrm{z}$ drugiej zaś strony spowodują $\mathrm{u}$ recypienta odpowiednie działanie - reakcję mentalną i idący za nią bezpośrednio śmiech.

Grunberger pisze, iż „humor antynazistowski był zarówno minimalnym wyrazem oporu (albo przynajmniej dezaprobaty), jak i formą terapii." (1987, s. 395). W tekście niemieckim ostatni akt mowy zawierający ironiczne przypuszczenie, będące źródłem takiego właśnie humoru, różni się zdecydowanie od polskiej wersji: Tu mamy stwierdzenie, że gdyby Hitler jeszcze trochę poczekał, zanim przystąpił do narodowych socjalistów, to być może szybciej zostałby Führerem. Zatem nie implikuje się w tym akcie mowy niczego ponad to, do czego Hitler finalnie doszedł, czyli do stanu faktycznego:

Erster Mann: Ist dir aufgefallen, wie die Märzgefallenen es geschafft haben, alte Parteigenossen wie dich und mich hinter sich zu lassen?

Zweiter Mann: Du hast recht. Hätte Hitler auch noch ein bißchen gewartet, ehe er zu den Nationalsozialisten ging, wäre er vielleicht schneller Führer geworden.

(Kerr, 2007, s. 11) 
W wypowiedzi pierwszego mężczyzny także objawił się ekspresywny charakter tego aktu mowy, jednak tu w pierwszym rzędzie akcentuje się fakt, iż to właśnie te marcowe fiołki dokonały konkretnych działań, które pozostawiły w tyle „dawnych towarzyszy partyjnych” i pada pytanie, czy rozmówca to zauważył. Sens pozostaje podobny, jednak pytanie powoduje, że oczekiwana jest odpowiedź na nie, stanowiąca dla pierwszego rozmówcy potwierdzenie.

\section{Ironia jako broń jednostki w walce $\mathrm{z}$ systemem}

W powieści pojawiają się dwa rodzaje nadawcy, których język stanowi przedmiot szczególnego zainteresowania niniejszego artykułu: jest to z jednej strony sam główny bohater - Bernhard (Berni) Gunther, przedstawiciel społeczeństwa epoki narodowego socjalizmu w Niemczech, z drugiej strony są to inni jemu podobni - ci, których łączy podobne postrzeganie rzeczywistości, podobna postawa wobec świata, w którym przyszło im żyć. Zatem za wspomnianą już wcześniej grupę społeczną, której język podlega tu analizie, postrzegać należy naród jako twór społeczny w szerszym kontekście, a także postać samego bohatera, jako członka owego narodu, a jednocześnie jako osobę stojącą w opozycji do większości społeczeństwa. Berni Gunther to bohater archetypowy, prezentujący określone wzory postępowania, a wraz z nimi powszechnie uznawane za pożądane normy i wartości, przez co jest nieco zbyt wyidealizowany $\mathrm{w}$ kontekście opisywanej epoki i dość przewidywalny w działaniu i słowach, ale także posiadający znaczny potencjał dla analiz językoznawczych.

Ironia jako jeden $\mathrm{z}$ językowych środków wartościowania stanowi broń głównego bohatera $\mathrm{w}$ walce $\mathrm{z}$ systemem. Jako iż postać bohatera jest typowa dla omawianego gatunku tekstu, posiada on cały zestaw cech osobowościowych oraz reprezentuje wzorce zachowań, charakterystyczne dla takiego właśnie przedstawiciela grupy społecznej. Bernhard Gunther to mężczyzna w sile wieku, były oficer policji kryminalnej, a obecnie prywatny detektyw, korzystający, nierzadko w nadmiarze, z typowych dla jego czasów używek chętnie sięgający po papierosy, alkohol, nie stroniący od towarzystwa „pań lekkich obyczajów".

Berni Gunther prezentuje cały zestaw cech charakteru, spodziewanych po takim właśnie typie bohatera: jest cyniczny, inteligentny, dowcipny, bezkompromisowy i odważny - choć odwaga często graniczy u niego z brawurą. Jednak tym, co wyróżnia tę postać na tle wszystkich innych w powieści jest właśnie język jakim się posługuje. Język cięty, język 
uszczypliwy, język szyderczy. Dołączając do tego wisielczy humor, cięte riposty i sarkastyczny sposób wysławiania się otrzymujemy jako efekt finalny barwną postać, której język właśnie zasługuje na szczególną uwagę. Gunther reprezentuje charakterystyczną dla stolicy manierę mówienia tzw. Berliner Schnauze, czyli bezpośredni sposób wypowiadania się, mówienia wszystkiego, „co ślina na język przyniesie”, bez ogródek, nie dbając o to, jak jego słowa odbiorą inni. W kontekście czasów, w których przyszło mu żyć oraz roli, jaką przyszło mu pełnić, to właśnie sarkazm i wisielczy humor pozwalają mu przetrwać trudne chwile i stanowią rodzaj tarczy zabezpieczającej go przed ponurą rzeczywistością. Z charakterystyczną dla siebie "delikatnością" stwierdza:

Przyjmuję zlecenia dotyczące śledztw w sprawach ubezpieczeniowych, pilnuję ślubnych upominków i staram się odnaleźć osoby zaginione. Tak, odkąd nastał narodowy socjalizm, w tej dziedzinie bardzo zwiększyło się zapotrzebowanie na moje usługi. [...] Cóż, wszyscy skorzystaliśmy na objęciu władzy przez nazistów. Prawdziwe z nas „marcowe fiołki”. (Kerr, 2014, s. 12)

Ich arbeite für Versicherungen, bewache Hochzeitsgeschenke und suche vermißte Personen - solche, von deren Verschwinden die Polizei noch nichts weiß, aber auch andere, deren Verschwinden gemeldet ist. Ja, das ist ein Bereich meines Geschäfts, der seit der Machtübernahme richtig aufgeblüht ist.» [...] «Ich denke, wir haben alle ganz hübsch vom Nationalsozialismus profitiert, nicht wahr? Richtige kleine Märzgefallene.» (Kerr, 2014, s. 16)

Ironia (także częsta autoironia) stanowiąca oś wszelkich wypowiedzi bohatera wynika $\mathrm{z}$ jego zdroworozsądkowego w istocie rzeczy oglądu świata i idącej za tym silnej potrzeby sprawiedliwości społecznej. Potrzeba ta została silnie zachwiana przez system państwowy, pozostała mu zatem wiara we własne poczucie sprawiedliwości połączona z wiarą we własną niezniszczalność i potrzebą samostanowienia. Te właśnie czynniki wpływają na jego sposób wysławiania się, myślenia, odczuwania:

[...] Pan zaś musi być - tu udałem, że czytam jego wizytówkę - doktorem Fritzem Schemmem, germańskim adwokatem. - Słowo „germańskim” wymówiłem z naciskiem niepozbawionym ironii. Kiedy widziałem je na wizytówkach czy szyldach, zawsze budziło we mnie niechęć, podkreślało rasową nieskazitelność. A w tym przypadku, skoro Żydom i tak nie wolno było wykonywać zawodu prawnika, było zbędne. Oznaczało tylko wyznanie wiary. Nigdy nie określiłbym siebie mianem "germańskiego prywatnego wywiadowcy”, równie dobrze mógłbym nazywać się „wywiadowcą antysocjalistycznym”, „wywiadowcą owdowiałym” lub „wywiadowcą luterańskim”. Wszystko to byłoby prawdą, choć ostatnie już niepełną, bo dawno przestałem chodzić do kościoła. (Kerr, 2014, s. 18) 
Ten sposób bycia i budowania wypowiedzi zdają się predestynować bohatera do miana bohatera walczącego $\mathrm{z}$ systemem (teoretycznego antybohatera). Widzi on tragikomizm sytuacji i stara się wyrazić swoją dezaprobatę, do czego wykorzystuje właśnie ironię. Berni Gunter mówi wprost co myśli, a ironia i cynizm w jego wypowiedziach stają się jego bronią. Takie zachowania werbalne ukazują jego kręgosłup moralny - w kontekście ówczesnego społeczeństwa oznaczały one sprzeciw, formę dezaprobaty wobec rzeczywistości, a w związku z tym mają nacechowanie silnie wartościujące. Ironia jako językowy środek wartościowania stanowi w jego przypadku narzędzie samoobrony, mechanizm wspomagający bohatera $\mathrm{w}$ uporaniu się z sytuacją, pozwala przykryć swą bezradność i brak możliwości samostanowienia. Jako że $\mathrm{w}$ jego otoczeniu panuje zgoda społeczna, ogólnospołeczne przyzwolenie na taki sposób funkcjonowania, z którym on walczy, jego sposób myślenia i wyrażania owych myśli stanowią przejaw przeciwstawienia się jednostki wobec totalitaryzmu - wykraczającego w każdą sferę życia - w tym także język.

Bernie Gunter jako były policjant zna język przestępców, posługuje się nim, stara się $\mathrm{w}$ ten sposób dopasować do rozmówcy, opierając wypowiedzi nierzadko na wspomnianej już dychotomii my $\neq$ oni. My, czyli w strukturze makro naród - ten aspekt stanowi częste źródło kpin (np.: Zatem Paul Pfarr należał do naszych czarnych aniołów! (Kerr, 2007, s. 50)) oraz my w kontekście mikro - jako ci dobrzy, myślący, walczący z przymusowym zaszeregowaniem społecznym, nie bojący się, podobni sobie, o zbieżnych poglądach. Język i ironia zatem łączą bohaterów, dają im iluzoryczne poczucie bezpieczeństwa, a dzisiejszemu odbiorcy pozwalają zaobserwować w jaki sposób zawiązywały się wówczas znajomości i wzajemne zależności.

\section{Leksykalny obraz wyrażania wartości i ironii w kontekście aktów mowy}

Analiza o podłożu socjolingwistycznym nie może się rzecz jasna obejść bez uwzględnienia w niej leksykologii, gdyż jak stwierdza Shumarova (2004: s. 27):

Socjolingwistyka zagłębia się w poszukiwaniu korelacji i zależności pomiędzy stosowaniem słowa i społecznymi parametrami mówiących, dąży do ustanowienia preferencji przy wyborze wariantów i wyjaśnienia podobnych faktów. (cytuję za Trysińska, 2015, s. 47) 
Sentencja wprowadzająca, umieszczona jako pierwsze zdanie powieści, stanowi interesujący przykład aktu mowy o wydźwięku ironicznym, nacechowanego emocjonalnie, ukazującego przy użyciu pośredniego aktu mowy:

Dziwniejsze rzeczy zdarzały się już w mrocznych snach Wielkiego Przywódcy... Merkwürdige Dinge ereignen sich in den dunklen Träumen des Großen Verführers...

Wersja niemieckojęzyczna, czyli rzeczownik Verführer, stworzony w wyniku afiksacji - poprzez dodanie sufiksu słowotwórczego -er dla uzyskania formy rodzaju męskiego oraz prefiksu ver- modyfikującego znaczenie, semantycznie opiera się na relacji leksemów Führer - Verführer ${ }^{12}$, na swoistej grze słów. Poprzez fakt, iż fraza der Große Verführer ${ }^{13}$ zawiera w sobie jako integralną część leksem Führer, staje się ona pojemniejsza semantycznie, o silnie (tu z definicji pozytywnie) wartościującym nacechowaniu semantycznym i wywołuje poprzez to szersze skojarzenia niż fraza polska Wielki Przywódca. Nazistowski neologizm Führer służył zarówno jako tytuł, jak również jako epitet, a oparty na modelu faszystowskim był absolutnie związany z postacią Hitlera. Pojawił się on w latach dwudziestych XX wieku. Okrzyknięcie Hitlera „naszym Führerem” przez Hermanna Essera podczas publicznego wystąpienia w cyrku Krone (Zirkus Krone) 29 lipca 1921 roku, w wieczór jego wyboru na przewodniczącego NSDAP, odpowiadało obowiązującemu powszechnie i przyjętemu na zasadzie zgody społecznej aktowi użycia języka (por. SchmitzBerning, 2000, s. 241-242). W tym kontekście i w tej epoce bycie Wielkim Przywódcą stanowi immanentną wartość systemu, a pisownia wielkimi literami jeszcze wyraźniej ten fakt uwypukla. Każdy z tych aktów mowy stanowi ciekawy przykład pośredniego aktu mowy, gdyż odczytując je należy każdorazowo uwzględnić kontekst - niewątpliwie dzieją się rzeczy dziwne, jednak bywały już sytuacje dziwniejsze. Wielokropek kończący frazy ukazuje stosunek emocjonalny autora do opisywanej w ten sposób rzeczywistości, to

12 Więcej na temat konceptualizacji leksemu Führer jako jednostki wartościującej patrz: Kukowicz-Żarska (2019, s. 114-115).

${ }^{13}$ Co ciekawe kolokacja der Große Verführer pojawia się w języku niemieckim także w nieco innym znaczeniu niż proponowane tutaj, t.j. jako 'wielki amant kina', czemu odpowiadać może właśnie polski termin amant lub uwodziciel. - np. Der Große Verführer jako niemiecki tytuł filmu Don Juan z 1956 roku w reżyserii Johna Berry’ego (pl. Miłość Don Juana). W tym przypadku dopatrzyć się można również pewnej motywacji w kontekście powieści: uwodzicieljako 'ten, który uwiódł naród i pociągnął go za sobą, za wyznawanymi przez siebie ideami'. 
niedopowiedzenie, zapowiedź czegoś, co nie ma być skonkretyzowane lub nie powinno być powiedziane wprost.

Nie tylko rozpoznanie intencji nadawcy stanowi kluczowy element interpretacji wypowiedzi, niezbędne jest również znajomość kontekstu oraz sytuacji socjokulturowej, np. by rozszyfrować następujące eufemizmy:

pilot sportowy (Sportflieger) - $\mathrm{w}$ znaczeniu 'pilota przechodzącego tajne szkolenie bojowe':

Oczywiście nie trzeba być detektywem, by odgadnąć, że „pilot sportowy” to jeden z tych ozdobnych hitlerowskich eufemizmów, oznaczający po prostu pilota przechodzącego tajne szkolenie bojowe. (Kerr, 2014, s. 12)

Natürlich brauchte man kein Detektiv zu sein, um darauf zu kommen, daß «Sportflieger» eine dieser phantasievollen Umschreibungen der Nazis war und sich auf die geheime Ausbildung von Kampffliegern bezog. (Kerr, 2007, s. 16)

czy czarne anioły - w znaczeniu 'członka SS':

Zatem Paul Pfarr należał do naszych czarnych aniołów! (Kerr, 2007, s. 50)

Paul Pfarr war also ein schwarzer Engel (Kerr, 2014, s. 55)

Ciekawym z punktu widzenia analizy językowej zdaje się już pierwszy fragment powieści - czyli dwa pierwsze zdania (pomijając poprzedzającą je sentencję omawianą wcześniej), wprowadzające odbiorcę do świata, w który zanurza się coraz głębiej w miarę czytania:

This morning, at the corner of Friedrichstrasse and Jägerstrasse, I saw two men, S A men, unscrewing a red Der Stürmer showcase from the wall of a building. Der Stürmer is the anti-Semitic journal that's run by the Reich's leading Jew-baiter, Julius Streicher. (Kerr, 1989),

które w języku polskim otrzymało zbliżone brzmienie:

Owego ranka zobaczyłem na rogu Friedrichstrasse i Jagerstrasse, jak dwóch facetów z SA zdejmuje ze ścian budynku czerwoną gablotę "Sturmera”. „Der Sturmer” to antysemicka gazeta wydawana przez głównego żydożercę Rzeszy, Juliusa Streichera. (Kerr, 2014, s. 9).

Zastanawiającym zdaje się $\mathrm{w}$ fakt, iż $\mathrm{w}$ niemieckim wydaniu zabrakło tłumaczenia jednego z przytoczonych powyżej zdań, zdania drugiego, które teoretycznie stanowi akt mowy o funkcji informującej, jednak użyta jednostka leksykalna o silnym nacechowaniu negatywnym powoduje, że wyraźnie zaznacza się tu jego ekspresywny charakter. W związku z tym omawiany fragment w tekście niemieckim brzmi następująco: 
Heute morgen sah ich an der Ecke Friedrichstraße und Jägerstraße zwei SAMänner, die einen roten Schaukasten des Stürmers von der Mauer eines Gebäudes abschraubten. (Kerr, 2007, s. 13)

Zdanie drugie zatem zostało całkowicie pominięte $\mathrm{w}$ tekście niemieckim - być może przez przeoczenie - choć fraza ta znajduje się na samym początku powieści - na jej pierwszej stronie. Brak owego, zdawałoby się nie niezbędnego dla zrozumienia treści powieści zdania, prowadzi do pewnej komplikacji w odbiorze tekstu, gdyż w kontekście struktury tworzy ono wraz z ostatnim zdaniem powieści swego rodzaju klamrę, spinającą całość:

Czerwone gabloty „Sturmera” wróciły na rogi ulic, a gazeta Streichera zionęła jeszcze większym jadem. (Kerr, 2014, s. 302)

Die roten Schaukästen des Stürmers hingen wieder an den Straßenecken, und Streichers Hetzblatt schien womöglich noch mehr zu hetzen als je zuvor. (Kerr, 2007, s. 339)

W tekście niemieckim pojawia się wspomniana powyżej fraza jako element zamykający powieść, jednak z powodu braku frazy wprowadzającej zmniejsza się efekt jej oddziaływania. Pominięcie zatem tego silnie nacechowanego wartościująco aktu mowy powoduje, że obok zaburzenia ramy formalnej powieści, redukuje się jednocześnie $\mathrm{w}$ takim przypadku siła wpływu owego aktu mowy na odbiorcę.

\section{Wnioski końcowe}

Oczywistym jest, iż w niniejszym tekście dotyczącym wartościowania ocena opisywanych zagadnień $\mathrm{w}$ świetle wartości uniwersalnych oraz prawdy historycznej winna być jednoznacznie negatywna. Ponieważ jednak na plan pierwszy wysuwa się tu analiza językoznawcza, która by być wiarygodną i odpowiadającą poczynionym na początku tego artykułu założeniom, powinna być ona wielowymiarowa i nie może $\mathrm{w}$ niej zabraknąć refleksji nad istotą omawianych zjawisk. Ze względu na delikatną materię omawianej problematyki starałam się nie oceniać omawianych fenomenów językowych w kontekście ich wymiaru moralnego, a jedynie prezentować przykładowe akty mowy, zestawiać ze sobą ich realizacje w obu językach (niemieckim i polskim), wyjaśniać konteksty, źródło ironii czy wartościowania, ukazywać potencjalny wpływ aktu na odbiorcę. Jednocześnie zdając sobie sprawę, iż omawiany $\mathrm{w}$ artykule sposób retoryki stanowi pewną formę reprezentacji przeszłości i pamięci, staram się traktować temat w sposób naukowoobiektywny i tym samym świadomie oddalić się nieco od założeń kultury 
pamięci (Erinnerungskultur), by nie naruszyć jej założeń i zasad nią kierujących.

\section{BIBLIOGRAFIA}

Austin, J. (1993). Mówienie i poznawanie. Rozprawy i wykłady filozoficzne (przekł. Bohdan Chwedeńczuk). Warszawa: Wydawnictwo Naukowe PWN.

Grabias, S. (2019). Język w zachowaniach społecznych Podstawy socjolingwistyki i logopedii. Lublin: Wydawnictwo Uniwersytetu Marii Curie-Skłodowskiej. ISBN 978-83-227-9122-6

Drozdowicz, J. (2010). Nazistowski okultyzm a niemiecka koncepcja narodu i wspólnoty. Przegląd Religioznawczy, 1 (235), 47-57.

Garlicki, A. (25 czerwca 2009). Kryminał wpisany w historię. Polityka. Dostęp online: https:/www.polityka.pl/tygodnikpolityka/kultura/ksiazki/294985,1,recenzja-ksiazkiphilip-kerr-marcowe-fiolki.read (data dostępu: 14.07.2020)

Grunberger, R. (1987). Historia społeczna Trzeciej Rzeszy. (przekł. pol.: Witold Kalinowski), t. I i II. Warszawa: Państwowy Instytut Wydawniczy. ISBN: 83-06-01389-1

Kerr, P. (2007). Die Berlin-Trilogie. (przekł. Hans J. Schütz). Reinbek bei Hamburg: Rowohlt (Inhalt: Feuer in Berlin - Im Sog der dunklen Mächte - Alte Freunde, neue Feinde). ISBN 978-3-499-24465-0

Kerr, P. (2014). Marcowe fiołki. (przekł. Ewa Fiszer). Warszawa: W.A.B. ISBN: 978-83-280-09462

Kukowicz-Żarska, K. (2019). Zur Wirkung der Worte. Sprachliche Bewertungsmittel als Indikatoren der Wortskraft in der emotionsbezogenen NS-Sprache. Forum Filologiczne Ateneum, (1(7)2019), 105-122. https://doi.org/10.36575/2353-2912/1(7)2019.105

Kukowicz-Żarska, K. (2018). O wartościowaniu i prawdzie w języku i tekście. Język narodowego socjalizmu w perspektywie językoznawczej i socjokulturowej. Forum Filologiczne Ateneum, (1(6)2018), 61-86. https://doi.org/10.36575/2353-2912/1(6)2018.061

Lipczuk, R. (2000). O wielości i wieloznaczności terminów (na przykładzie klasyfikacji aktów mowy). Acta ac Communitas, 9, 169-176.

Schmitz-Berning, C. (2000). Vokabular des Nationalsozialismus. Berlin, New York: Walter de Gruyter.

Trysińska, M. (2015). Akty mowy jako klucz do interpretacji postaw rodzicielskich. Wychowawcze, komunikacyjne $i$ edukacyjne aspekty filmów animowanych dla dzieci (na przykładzie filmów emitowanych w MiniMini+ i Cartoon Network). Warszawa: Wydział Polonistyki Uniwersytetu Warszawskiego.

Zdunkiewicz, D. (1993). Akty mowy. W: Bartmiński, J. (red.) Encyklopedia kultury polskiej XX wieku, t. 2, Współczesny język polski (ss. 259-270). Wrocław: Wydawnictwo: "Wiedza o kulturze". 
